\title{
An Epidemiological Analysis of Deaths Due to Burns in Newly Married Females
}

\author{
Nisreen Abdul Rahman ${ }^{1}$, Shanmugam K. ${ }^{2}$, Sanjay Sukumar ${ }^{3}$, Kusa Kumar Shaha ${ }^{4}$ \\ ${ }^{1}$ Assistant Professor, Department of Forensic Medicine \& Toxicology, KMCT Medical College, Kozhikode, Kerala, \\ ${ }^{2}$ Assistant Professor, Department of Forensic Medicine \& Toxicology, Government Villupuram Medical College, \\ Villupuram, Tamilnadu, ${ }^{3}$ Additional Professor,Department of Forensic Medicine \& Toxicology, Jawaharlal Institute \\ of Postgraduate Medical Education and Research (JIPMER), Puducherry, India, ${ }^{4}$ Professor, Department of \\ Forensic Medicine \& Toxicology, JIPMER, Puducherry, India.
}

\begin{abstract}
Death due to burns is a major public health problem worldwide. Most cases occur in middle and low-income countries. In India, deaths due to burns are commoner in women than in men. Fire is easily available weapon for suicide and homicide and it can also cause accidental deaths. Death due to burns in newly married female is a common incident in our country and major fraction of such deaths happen as a result of dowry harassment or killing for not giving dowry. Our study aimed to identify some of the epidemiological factors in deaths due to burns in newly married females in and around Pondicherry. Out of 48 cases during the study period, 24 victims were in the age group of 22-25 years and 26 women died within 3 years of marriage. The majority of the cases occurred in less educated and homemaker wives and were living in a joint family. Major reasons or motive behind deaths were dowry harassment and torture, and quarrel with husband or inlaws. The most common manner of such deaths was suicidal followed by accidental.
\end{abstract}

Keywords: Burns; newly married females; dowry deaths; cooking accidents.

\section{Introduction}

Violence against the female is a global public health issue and violation of human rights of a woman. India has already entered into the so-called digital era, but Indian women are frequently exploited and victimized even after the continuous campaigns for equality and social justice.

Burns is a major public health problem. It is estimated that around 180000 deaths occurs annually due to burns. Major portion of such deaths occur in lowand middle-income countries. When we come to India

\section{Corresponding Author:}

\section{Dr. Nisreen Abdul Rahman}

Assistant Professor, Department of Forensic Medicine \& Toxicology, KMCT Medical College, Manassery, Kozhikode, Kerala, India e-mail:nisrali2@gmail.com

Mobile No.: 9626656223 more than $10,00,000$ people are moderately or severely burnt every year. The incidence is more common in females than in males. The increased risk for females is associated with cooking in open fire, unsafe kerosene cooking stoves, loose clothing which can ignite easily, self directed violence or interpersonal violence. The fire is easily available weapon for both suicide and homicide. $^{1}$

There are so many reported cases of suspicious death of newly married females. Burns is a major cause of such deaths in newly married females and could be of any manner. ${ }^{2,3,4}$ In many cases burns in newly married females claimed as stove burst or cooking accidents by husbands and in-laws, and later, it may be converted into the homicide or suicide-related to dowry issues. So our law suggests that any suspicious death of a woman within seven years of her marriage should be considered as a case of dowry death unless proved otherwise by the accused. $^{5}$

Only a few studies are conducted to analyze various 
factors of death due to burns in newly married females. In this study we tried to explore some epidemiological aspects of deaths due to burns in newly married females brought for the autopsy to the department of Forensic Medicine and Toxicology, JIPMER, Pondicherry during the study period.

\section{Materials and Methods}

This is an epidemiological descriptive study. All female deaths due to burns within seven years of marriage from January 2014 to June 2015, reported in the Department of Forensic Medicine, subject to inclusion and exclusion criteria were selected for the study.

Inclusion Criteria: Autopsy on newly married female deaths due to burns within seven years of marriage.

\section{Exclusion Criteria:}

1. The autopsy on unidentified female bodies

2. The autopsy on decomposed female bodies

Age, duration of married life, time and place of occurrence, type of family, occupation, educational status and socio-economic status of victim, occupation of victim's husband, reason behind death and manner of death were the parameters under study. A descriptive study was conducted to address the study objectives. All cases of married female deaths due to burns within seven years of marriage brought in the department of Forensic Medicine and Toxicology, JIPMER for autopsy in which all inclusion and exclusion criteria satisfied during the study period were considered eligible for the study.

After receiving the inquest report given by the investigating officer, the history of the case is obtained from the police personnel. The hospital records referred, in the hospital admitted cases. The history of the case from the relatives also recorded. A detailed external and internal examination carried out and the viscera for toxicological analysis and organ bits for histopathological examinations were taken as per the case.

All the data were analyzed using Microsoft excel sheets.

Ethics: The study was approved by the Institutional Ethics Committee, JIPMER

\section{Results}

The total number of cases autopsied during the study period from January 2014 to June 2015 (18 months) were 1254 cases, of which $36.36 \% \quad(n=456)$ cases constituted female deaths. In these 456 cases, 65 cases (5.18\% of total autopsies) were newly married female deaths. But only 48 cases $(3.82 \%$ of total autopsies) were female deaths due to burns within seven years of marriage. The age group of the cases brought to our hospital was ranging from $19-38$ years. About half of them $(50 \%)$ were in the age group of $22-25$ years (Fig no. 1$)$. About $56.17 \%(n-26)$ of them died within 3 years of marriage and $87.5 \%$ died within 5 years of marriage. Only 3 cases occurred within a year of marriage (Table no.1).Most of the incidences occurred in the rural area $(87.5 \%)$ as compared to urban (12.5\%). About $62.5 \%$ of them were living in joint family and rest were from the nuclear family (37.5\%). About two-third of burns $(66.7 \%)$ happened during night hours (i.e. 6 pm-6 am) and rest (33.33\%) during the daytime.

We noticed that $66.67 \%$ of them were coming from low-income families and $31.25 \%$ from middle-income families. Only $2.1 \%$ were high-income families. About $25 \%(\mathrm{n}-12)$ of them had upper primary level, $52.68 \%$ (n- 25) high school level, 16.67\% (n-8) higher secondary level of education. Only $6.25 \%(n-3)$ were graduates. None of them were professionals or postgraduates. None of them were illiterates or lower primary level (Fig.no.2). Out of 48 deceased women, 40 were homemaker wives, 5 were daily labourer, and 3 employed in private firms.

From our study, we observed that about $56.25 \%$ of victim's husbands were daily labourers followed by $22.92 \%$ own business runners and $14.58 \%$ employed in the private/government sector. About $6.25 \%$ of them were without any jobs (Fig.no.3). The reason/motive behind death is illustrated in Table no.2. Out of 48 cases, 28 cases were suicidal, 18 accidental, and 2 homicidal cases. But at the end of our study, some of the cases got altered to different manners on inquiry to the police station by phone calls. Two suicidal cases got altered to homicides, and two accidental cases got altered to one homicide and one suicide.

\section{Discussion}

Indian law states that any suspicious death of a married woman within 7 years of her marriage is considered to be a case of dowry death unless proved otherwise by the defendants. ${ }^{5}$ The age of victims in $50 \%$ of women was between $22-25$ years. Singh J et al. also found that $37 \%$ of dowry death cases occurred in $22-25$ 
years of age. ${ }^{6}$ On further exploration, we can see that about $70.83 \%$ of cases were in $18-25$ years age group, which was similar to the study by Radhika RH et al. ${ }^{7}$

Women in 2-3 years of marriage constituted the single most vulnerable group from our study $(29.16 \%)$. Srivastava AK et al. observed as $60 \%$ of women died within three years of marriage and were similar to our study $(56.17 \%) .{ }^{4}$ As per Radhika $\mathrm{RH}$ et al., this was found to be increased to $73.3 \% .^{7}$ The reasons for the fewer number of cases in the first year of marriage may be the pressure from her parents to adjust or maybe her silent suffering to cope with the situation. But at one point they feel so agitated and may commit suicide.

In our study, most of the incidents occurred in rural areas (87.5\%) as compared to the urban area. Darji JA and Radhika RH observed the cases from the rural area as $57 \%$ and $56 \%$ respectively. ${ }^{7,8}$ The increased percentage in our case may be due to the higher number of the rural population in our study area. Most of them (62.5 $\%)$ were living in a joint family and these findings were comparable to the study by Nuchhi UC et al., Mohanty $\mathrm{S}$ et al. and Arora $\mathrm{P}$ et al..$^{9,10,11}$ About two-third of burns happened during night hours. Agnihotri A et al., Nuchhi $\mathrm{UC}$ et al. and Mohanty $\mathrm{S}$ et al.also observed a higher rate of incidents in night hours. ${ }^{2,9,10}$

Most of them were from a low-income family and the results were comparable with the findings of Sinha US et al. and Das RK et al. ${ }^{3,12}$ About half of them studied only up to high school level and one fourth only up to upper primary level. None of them were professionals or postgraduates. Arora $\mathrm{P}$ et al. and Nuchhi UC et al. also got similar observations. ${ }^{11,9}$ In our study None of the victims were illiterates and the reason may be the increased facility and incentives for education in our study population. Majority of them were homemaker wives and the findings were similar to the studies by Srivastava AK et al. and Sinha US et al., ${ }^{4,3}$

In $25 \%$ of the cases, there was definite harassment and torture for dowry and in $31.25 \%$ of the cases, there was a quarrel with spouse or in-laws for demanding cash or kinds from her family, alcoholism of husband, and harsh behaviour of husband and in-laws. These two were the main reasons behind the deaths. Srivastava AK et al. and Arora $\mathrm{P}$ et al. also noticed similar findings. ${ }^{4,11}$ About $40 \%$ of the cases claimed to be accidental burns. At this point, we have to emphasize the observation made by $\mathrm{McCoid} \mathrm{CH}$ that the alleged "cooking accidents" may not be true every time which can be homicide or suicide. ${ }^{13}$ The victims' relatives won't go for further legal proceedings as they are from poor socioeconomic status, less educated and they won't get back their daughter.

In our study, about $58.3 \%$ of cases were suicidal burns followed by $37.5 \%$ accidental burns and $4.1 \%$ homicidal burns. The findings of Mohanty $\mathrm{S}$ et al., Radhika RH et al. and Darji JA et al. were matching with our findings. ${ }^{10,7,8}$ But Shaha KK et al. noticed that about $55 \%$ of dowry deaths due to burns were homicides. ${ }^{14}$ During our study, we experienced contradictory statements from relatives or attendants of the deceased in many accidental deaths to raise the suspicion of foul play. As shown before, some of the suicides and accidents got altered to homicides and suicides. There may be more alterations in IPC/CrPC sections after the study period as in many of the cases judicial actions not yet started. One of the reasons for this delay is high caseloads in our courts and police stations.

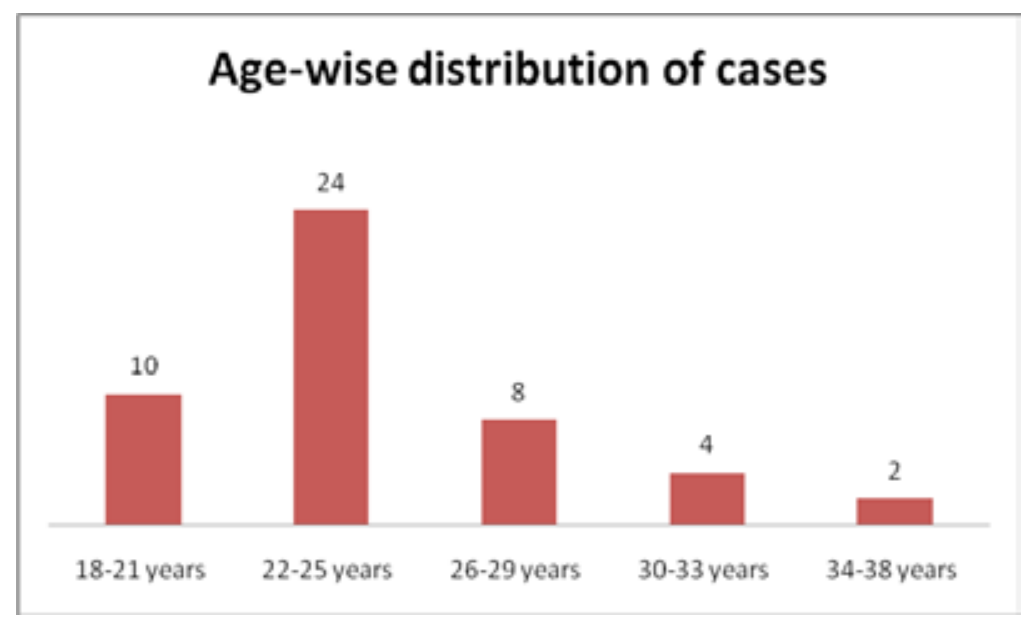

Fig. No. 1 : Shows the age-wise distribution of deaths due to burns in newly married females. 


\section{Educational status of the victims}

$$
\begin{aligned}
& \text { n Illiterate } \quad \text { Primary }(</=4 \text { th }) \\
& \text { a Primary ( 5th - 7th) = High School ( 8th - 10th) }
\end{aligned}
$$

$6 \% 0 \% 0 \%$

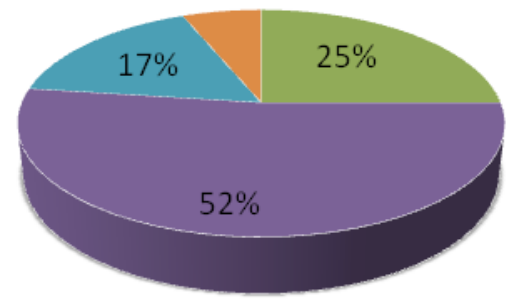

Fig. No. 2: Shows the educational status of victims in deaths due to burns in newly married females

\section{Occupation of victims' husband}

Daily laborer Employed $\quad$ Ownbusiness $\quad \mathrm{Nil}$

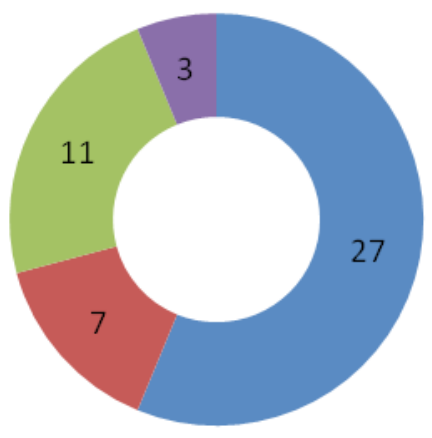

Fig. No. 3: shows the occupation of victims' husband in deaths due to burns in newly married females

Table No. 1: Shows the duration of married life in deaths due to burns in newly married females.

\begin{tabular}{|c|c|c|c|}
\hline Serial No. & Duration of married life in years & Number of cases & Percentage (\%) \\
\hline 1 & $<1$ & 3 & 6.25 \\
\hline 2 & $1-2$ & 8 & 16.67 \\
\hline 3 & $2-3$ & 14 & 29.17 \\
\hline 4 & $3-4$ & 13 & 27.08 \\
\hline 5 & $4-5$ & 3 & 6.25 \\
\hline 6 & $5-6$ & 4 & 8.33 \\
\hline 7 & $6-7$ & 2 & 4.17 \\
\hline
\end{tabular}


Table No. 2: shows the reason/motive behind deaths due to burns in newly married females.

\begin{tabular}{|c|l|c|c|}
\hline Serial No. & Alleged reason/motive behind the death & Number of cases & Percentage (\%) \\
\hline 1 & Quarrel with spouse/in-laws or both & 15 & 31.25 \\
\hline 2 & Accidental & 19 & 39.58 \\
\hline 3 & Dowry harassment and torture & 12 & 25 \\
\hline 4 & Infertility & 1 & 2.08 \\
\hline 5 & Illness & 1 & 2.08 \\
\hline
\end{tabular}

\section{Conclusion}

In this article, we tried to find out the magnitude of dowry deaths due to burns in the study population. This study may be only the tip of an iceberg. Also, many of the cases are not reported as dowry death due to poor education and lack of money to go for further legal action. In our study, only very few of the victims were well educated with a good job and from high socioeconomic status. This shows the importance of women empowerment by educating and helping her to get into a good occupation by the parents and relatives than simply marrying off her away with a huge dowry. Maintaining gender equality while rearing the children plays an important role in reducing such incidents. Proper premarital counselling of both spouses with an added education of the girl about her rights will also make an impact in decreasing such events.

\section{Conflicts of Interest: Nil}

Source of Funding: No fund utilized for the study.

\section{Reference}

1. World Health Organization. Burns. March 2018. [cited 2020 July 14 ]. Available from: https://www. who.int/news-room/fact-sheets/detail/burns.

2. Agnihotri A. The epidemiological study of dowry death cases with special reference to burnt cases in Allahabad zone. Anil Aggrawal's Internet J Forensic Med Toxicol. 2001 March; 2(1): [cited 2020 Jun 15 ] Available from: http://www.anilaggrawal.com/ij/ vol_002_no_001/theses/001/thesis001.html

3. Sinha US, Kapoor AK, Pandey SK. Medicolegal aspects of dowry death cases in Allahabad range (U.P). Int J Med Toxicol Leg Med. 2002;5(1): 3540.

4. Srivastava AK, Arora P. Suspicious deaths in newly married females - a medicolegal analysis. J Indian Acad Forensic Med. 2007;29(4):63-7.
5. Kumar V, Kanth S. Bride burning. The Lancet. 2004 Dec;364:18-9.

6. Singh J, Kaur J, Tandon RN, Shah KA, Patil VR, Kumar V. A medico-legal study of unnatural deaths in newly married females. J Indian Acad Forensic Med. 2014 Oct-Dec;36(4):355-8.

7. Radhika RH, Ananda K. An autopsy study of socioetiological aspects in dowry death cases. J Indian Acad Forensic Med. 2011 Jul-Sep;33(3):224-7.

8. Darji JA, Parmar AP, Bhagora RV, Panchal DN. Profile of suspicious deaths of women died within seven years of marriage life brought for postmortem examination at district hospital. Natl J Integr Res Med. 2013;4(5):30-2.

9. Nuchhi UC, Gannur DG, Yoganarasimha K. Evaluation of dowry related crimes in Bijapur city. Indian J Forensic Med Toxicol. 2012;6(2):209-13.

10. Mohanty S, Sen M, Sahu G. Analysis of risk factors of dowry death - a south Indian study. J Forensic Leg Med. 2013 May;20(4):316-20.

11. Arora P, Srivastava AK. Epidemiology of unnatural deaths in newly married females in Kanpur, UP. J Indian Acad Forensic Med. 2013 Apr-Jun;35(2):127-30.

12. Das RK, Debbarma A, Chakraborty PN. Profile of deaths of women within seven years of marriage in Agartala, Tripura. Medico-Legal Update. 2014 JulDec;14(2):14-7.

13. McCoid $\mathrm{CH}$. Dowry deaths in India: A materialist analysis. East Lansing: Michigan State University; 1989.

14. Shaha KK, Mohanthy S. Alleged dowry death: A study of homicidal burns. Med Sci Law. 2006 Apr;46(2):105-10. 